\title{
TTR
}

Traduction, terminologie, re?daction

\section{Albert Branchadell and Lovell Margaret West (eds.). Less \\ Translated Languages. Amsterdam/Philadelphia, John Benjamins Publishing, Benjamins Translation Library, EST \\ Sulbseries, vol. 58, 2005, vii + 414 p.}

\section{Lee Skallerup}

Volume 19, numéro 1, 1er semestre 2006

Figures du traducteur/Figures du traduire I

Figures of Translators/Figures of Translation I

URI : https://id.erudit.org/iderudit/016665ar

DOI : https://doi.org/10.7202/016665ar

Aller au sommaire du numéro

Éditeur(s)

Association canadienne de traductologie

ISSN

0835-8443 (imprimé)

1708-2188 (numérique)

Découvrir la revue

Citer ce compte rendu

Skallerup, L. (2006). Compte rendu de [Albert Branchadell and Lovell Margaret West (eds.). Less Translated Languages. Amsterdam/Philadelphia, John Benjamins Publishing, Benjamins Translation Library, EST Subseries, vol. 58, 2005, vii + 414 p.] TTR, 19(1), 205-209. https://doi.org/10.7202/016665ar

Tous droits réservés (c) TTR: traduction, terminologie, rédaction Les auteurs, 2007
Ce document est protégé par la loi sur le droit d'auteur. L'utilisation des services d'Érudit (y compris la reproduction) est assujettie à sa politique d'utilisation que vous pouvez consulter en ligne.

https://apropos.erudit.org/fr/usagers/politique-dutilisation/ 


\title{
COMPTES RENDUS
}

\begin{abstract}
Albert Branchadell and Lovell Margaret West (eds.). Less Translated Languages. Amsterdam/Philadelphia, John Benjamins Publishing, Benjamins Translation Library, EST Subseries, vol. 58, 2005, vii + 414 p.
\end{abstract}

This collection of essays was inspired in part by the $5^{\text {th }}$ International Conference on Translation, "Interculturality and Translation: Less Translated Languages," held in Catalonia, Spain, in October 2001. Translation studies is typically dominated by the analysis of translations between major languages (English, French, German, etc.), while those less-translated languages, languages that are in a subordinate position, are often ignored. One of the main purposes of this volume is to expand the field of lesser-translated languages, while at the same time exhibiting the variety of work currently done in the field of translation studies.

The Introduction concerns itself primarily with defining what is meant by the term "less translated languages." The idea of minority languages is of particular concern, given the current status of languages in the European Union, which prides itself as being multilingual, but only within the framework of each member country's official language(s). But the editors also wanted to include those languages that may be widely used, but not widely translated, usually due to a colonial situation, or an unequal power structure. Less translated languages, then, share a common experience of subordination. The editors also take a positive view of translation within less translated language groups, seeing it "as an opportunity for language maintenance and development" as well as "nation building" (pp. 8-9).

The essays in the first section, "English: The dominant language," takes a variety of approaches to the impact English has had on lesser-translated languages. Taking a statistical approach, Anthony Pym and Grzegorz Chrupala find "some empirical evidence that the percentages of translations from and to international languages cannot tell us how open or hegemonic a culture is” (p. 27), warning against basing translation policy (and theory) on statistics alone. Vilelmini Sosonis breaks down the challenges facing the EU as regards multilingual policy, especially in consideration of the dominance of English within the EU itself. Contemporary Tower of Babel or contemporary myth of the translators of the Septuagint, the EU 
provides a unique case study for maintaining the status of lessertranslated languages. Hassan Hamzé takes a linguistic approach in his analyses of the rapid evolution of Arabic using both English and French affixes, and the challenges this poses to translators. Nobel Perdu Honeyman looks at the landmark translations of the Kitáb-i-Aqdas or "Most Holy Book" of the Bahá'í Faith in both Spanish and French. The translation was done from both the original Arabic and English translation, using translators and experts from around the world, resulting in one of the largest projects involving both indirect and group translation. Finally, Maria D. Oltera Ripoll presents some of the challenges facing a translator when trying to reinterpret a Hollywood movie, in this case Pretty Woman, to a Spanish-speaking audience.

Part II, "Minority Languages: Facing inequality in the translation arena," consists of essays looking at minority languages, or languages in a minor position, from around the world, and focuses not so much on the how, but instead on the why behind the translations. Oscae Diaz Fouces places his focus on those non-official, thus minorised, languages in the EU, such as Catalan, Breton, Frisian, Scots, Welsh and Galician. He suggests a number of factors that should be taken into consideration when creating translation policies in the EU, particularly in order to protect these language groups against assimilation. Marta García González expands on Fouces framework, looking specifically at the multilingual situation in Nigeria, and proposes a type of sociology of translation in order to better understand the situation of minority languages. Albert Branchadell is concerned with mandatory translation, specifically the case of Catalan in Spain. While those living in areas where Catalan is the dominant language are guaranteed the right to use their mother tongue, certain aspects of general Spanish law do not recognize documents written in Catalan, thus forcing Catalan speakers into a situation of partial mandatory translation. Eva Espasa looks at a brief history of theatre translations and adaptations, and the unequal exchanges that take place therein. She specifically looks at French Quebec theatre for a contemporary example of spaces of resistance and subversion to those unequal exchanges. Anna Aguilar-Amat and Jean-Bosco Botsho take a neurobiological viewpoint towards the "obscured cultures" of subSaharan Africa. The role of the translator is especially difficult when faced with translating to and from sub-Saharan African cultures, as the West has typically obscured and misunderstood those cultures. 
Part III, "Translating from less translated cultures and languages," returns us to the how of translation. The first three essays by Goretti López Heredia, Andrés Xosé Salter Iglesias and Dora Sales Salvador concentrate on minor literatures written by former colonial subjects in the language of the colonialist. Heredia keeps us in Africa, concentrating on writers who have chosen to "translate" their African experiences, looking specifically at Ahmadou Kourouma and his transformation of the French language in his novel Allah n'est pas obligé. Iglesias focuses on Mia Couto, who is from Mozambique, but writes in Portuguese. Couto's "reorganizing” of Portuguese presents a number of challenges to the translator, in this case into Spanish, exaggerating the tension between the translator's invisibility and maintaining the "foreign" aspects of the original text. Salvador turns our attention to India, and those authors who would seem to be "transcreating" both language and literature, in this case, English. He takes a historical view, offering a sense of the evolution that has taken place within the "novel" in English written in India, and how both language and genre have become something distinctly Indian. Nicole Martínez Melis provides a descriptive analysis of the major translations of the Bodhicaryavatara, an $8^{\text {th }}$ century Buddhist treatise, while Leticia Herrero studies the project set forth by the publishing house Macmillan to translate Indian literature in languages such as Tamil, Malayalam, Oriya, Punjabi, Bengali and Marathi into English. The editors specifically decided to maintain a foreignised translation of the works, and Herrero studies both the positive and negative consequences of that choice in the case of Lamps in the Whirlpool, originally written in Tamil. Finally in this section, Sara Rovira-Esteva provides a number of approaches to overcome the challenges faced by those trying to translate Chinese measure words and dead metaphors.

The final two sections of the anthology focus on the specific minority language, Catalan. Part IV begins with a history of translation from Spanish to Catalan during the $20^{\text {th }}$ century by Monteserrat Bacardí. Bacardí focuses mainly on literary translations, and shows the impact of the Civil War and the dictatorship of Franco, as well as how translations helped to standardize the Catalan language. Cristina García de Toro picks up where Bacardí leaves off, focusing on translations between both languages at the present time. She does not limit the study to literary works, instead focusing on all types of translation, including television and movies, scientific writings and legal and administrative writings. What is interesting is the importance of the translation of adolescent and children's fiction within the structure of 
the two languages, specifically from Spanish to Catalan, as a result of laws requiring reading material in Catalan in schools. Irene Llop Jordana looks at the unique case of translation between two minority languages, in this case from Hebrew to Catalan.

The final section profiles six Catalan translators. Each of these figures had previously been recognized for other achievements, although their accomplishments and contributions as translators had been ignored. Judit Figuerola profiles the politician Andreu Nin, who was responsible for translating a number of Russian authors into Catalan. Judit Fontcuberta i Famadas places author Bonaventura Vallespinosa under the spotlight, who translated from Italian and French, including Camus, Molière, Pirandello, Racine, and Sartre. Alba Pijuan Vallverdú focuses on the translations of poet Manuel de Pedrolo, who translated French and American poetry, as well as novelists Faulkner, Miller, Salinger, and Steinbeck. The children's writer Josep Vallverdú is profiled by Anna Cris Mora, and his translations include the detective fiction of Raymond Chandler and Dashiell Hammet, the youth books of Jack London and Robert Louis Stevenson, as well as the works of Oscar Wilde, among many others. Pilar Godayol looks at feminist writer and translator Maria-Mercè Marçal, who produced translations of Colette and Marguerite Yourcenar. Jordi Arbonès i Montull, as outlined by Victòria Alsina Keith, managed a prolific career as a translator, despite censorship and dictatorship. Eventually translating over 40 works of literature, mostly novels, Montull helped introduce authors from Jane Austen and George Eliot, to C.S. Lewis and Tolkien, as well as D.H. Lawrence and Ernest Hemmingway, just to name a few. Each of these translators played an important role in maintaining the Catalan language and ensuring that generations of readers would be able to enjoy a wide variety of literature in their mother tongue.

This collection highlights a number of interesting developments within the field of translation studies over the past years. The wide variety of approaches to translations, from sociology to neurobiology, shows the truly interdisciplinary nature of the field. The specific subject of less translated languages illustrates just how rich and varied are the possible subject matters that have yet to be studied. The essays in this collection also help to illustrate some of the debates currently taking place within translation studies: descriptive versus prescriptive approaches, statistical analysis versus specific case studies, foreignisation versus adaptation, literary versus non-literary, written 
versus visual, etc...This collection not only opens up the study of less translated languages, a subject that had been ignored for far too long, but also shows why it is relevant and perhaps even essential to a greater understanding of translation and all that translation reveals to us.

\title{
Lee Skallerup \\ University of Alberta
}

\begin{abstract}
Antoine Berman (2003). La Prueba de lo ajeno: Traducción y cultura en la Alemania romántica. Trad. Rosario García López. Las Palmas de Gran Canaria, Universidad de las Palmas de Gran Canaria.
\end{abstract}

Dans l'introduction du numéro spécial de la revue TTR de 2001 (Vol. XIV, No. 2) consacré à Antoine Berman, Alexis Nouss affirme que : « la traductologie francophone s’est développée en lisant Berman [...] la discipline a vu son champ s'affermir, intellectuellement et institutionnellement, en parallèle avec la diffusion des ouvrages d'Antoine Berman. » (Nouss, 2001, p. 9). Selon Nouss, ce qui distingue la traductologie francophone des autres approches, ce ne sont ni les frontières géographiques ni les différences linguistiques. C'est le façonnement d'un savoir épistémologique de la traduction qui caractérise la traductologie francophone. Cette traductologie francophone de la fin du $\mathrm{XX}^{\mathrm{e}}$ et du début du $\mathrm{XXI}^{\mathrm{e}}$ siècles trouve dans L'épreuve de l'étranger d'Antoine Berman son propre manifeste, voire son œuvre maîtresse.

Voilà que paraît la version espagnole. Comme le déclare la traductrice, Rosario García López, dans sa préface, il était surprenant qu'il n'existe pas une traduction espagnole de cet ouvrage publié par Gallimard en 1984. Surprenant si l'on tient compte qu'il existe des œuvres qui exigent, qui demandent leur traduction car la traductibilité appartient à leur essence (Benjamin, 1997, p. 15). Le livre de Berman possède sans conteste cette caractéristique; il exige sa traduction.

Dans le discours traductologique contemporain, l'ubiquité de la pensée bermanienne, telle qu'exposée dans L'épreuve de l'étranger, exige sans aucun doute sa traduction en espagnol. Une exigence d'autant plus sentie si l'on considère que Berman était lui-même un hispaniste. Il est donc normal de se réjouir de la « renaissance » de cet ouvrage pour les lecteurs hispanophones. 